\title{
Rare presentation of porcelain gall bladder: carcinoma gall bladder with a large intra-abdominal cystic swelling
}

\author{
Sameer Gupta, ${ }^{1}$ Ramendra Kumar Jauhari ${ }^{2}$ \\ ${ }^{1}$ Department of Surgical Oncology, CSMMU (formerly K.G.M.C.), Lucknow, Uttar Pradesh, India \\ ${ }^{2}$ Department of General Surgery, S. N. Medical College, Agra, Uttar Pradesh, India
}

Correspondence to Dr Sameer Gupta, sameerdr79@gmail.com

\section{DESCRIPTION}

A 50-year-old woman was admitted with complaints of pain in the abdomen, a slowly growing painless lump in the central abdomen, anorexia and significant weight loss for the last 3 months. No history of jaundice, itching or fever. Physical examination revealed ovoid $15 \times 15 \mathrm{~cm}$ nontender cystic lump (figure 1) with restricted mobility in the mid-abdomen. CECT abdomen revealed malignant gallbladder mass with dense intramural calcification and multiple metastatic SOLs (space occupying lesions) in the liver (figure 2) with large cystic mass in the abdomen (figure 3). Fine-needle aspiration cytology (FNAC) from liver metastasis was positive for adenocarcinoma. Liver enzymes and $\alpha$-fetoprotein (AFP) levels were normal. Echinococcal antigen was negative. Pig-tail catheter drainage of cystic mass drained $\sim 1000 \mathrm{ml}$ clear cystic fluid following which pain and swelling subsided. Fluid cytology was negative for malignant cells. She was proposed to be started on palliative chemotherapy but her relatives refused further treatment.

Porcelain gall bladder is characterised by extensive calcification of the gall bladder wall with prevalence in cholecystectomy specimens between $0.06 \%$ and $0.8 \%$ and female predominance $(5: 1){ }^{1}$ It is associated with cholelithiasis in $95 \%$ cases. Risk of malignancy within porcelain gall bladder is $<10 \%{ }^{2}$ Stephen and Berger ${ }^{3}$ reported two

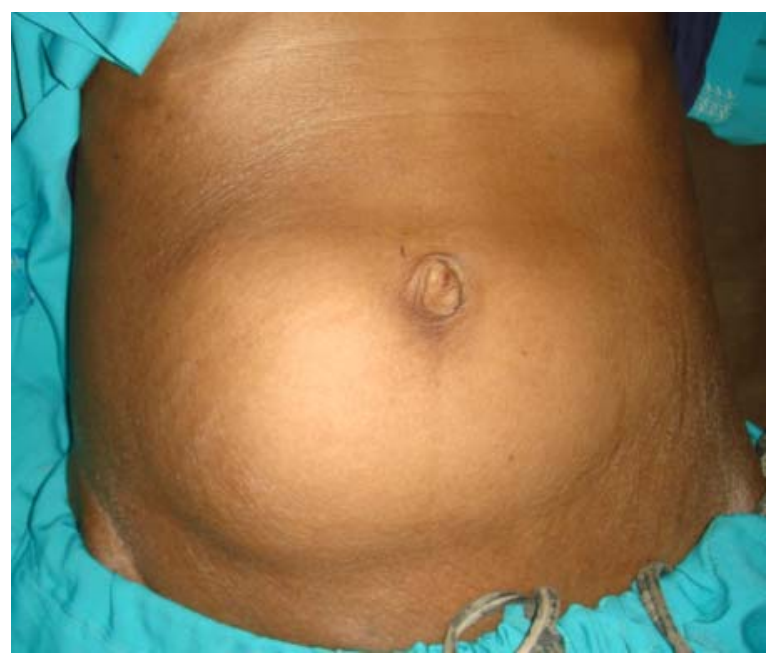

Figure 1 Intra-abdominal $15 \times 15 \mathrm{~cm}$ cystic swelling.

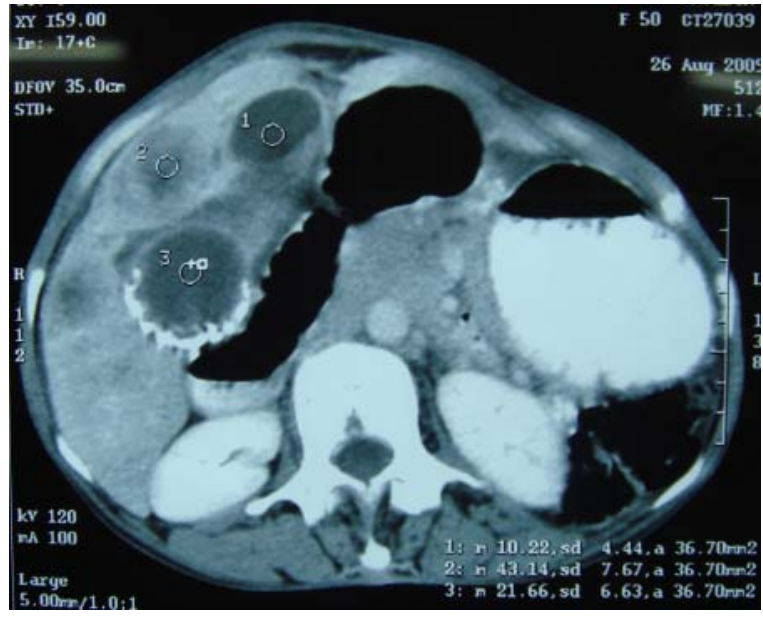

Figure 2 CECT scan showing porcelain gall bladder with multiple liver metastasis and formation of cystic swelling with no well defined origin.

patterns of gall bladder wall calcification: complete intramural calcification and selective mucosal calcification. Incidence of cancer arising in the former was negligible compared to risk of $7 \%$ in the former.

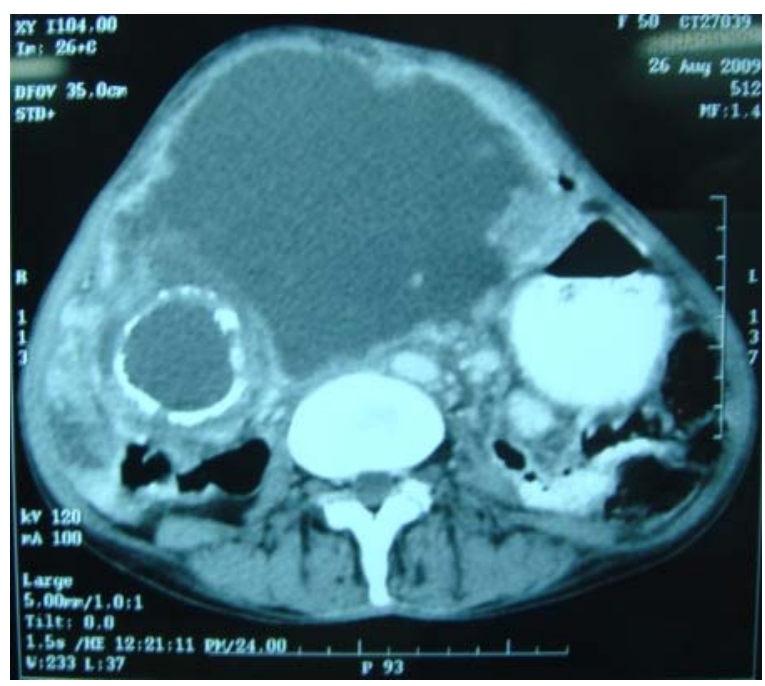

Figure 3 CECT scan showing porcelain gall bladder and large intra-abdominal cystic lesion pushing the bowel loops to the periphery. 


\section{BMJ Case Reports}

We report a rare case of malignant porcelain gall bladder who presented with large cystic intra-abdominal swelling and no features of intestinal obstruction or obstructive jaundice. Swelling subsided completely after pig-tail drainage. The origin of this swelling could not be conclusively ascertained despite extensive radiological imaging.

\section{Learning point}

- An unusual presentation of porcelain gall bladder with intramural calcification and malignant transformation with multiple liver metastasis but no obstructive jaundice/Intra hepatic biliary radical dilatation.

- Associated large serous cystic intra-abdominal swelling remained a diagnostic dilemma.
Competing interests None.

Patient consent Obtained.

\section{REFERENCES}

1. Cornell CM, Clarke R. Vicarious calcification involving the gallbladder. Ann Surg 1959;149:267-72.

2. Shimizu M, Miura J, Tanaka T, et al. Porcelain gallbladder: relation between its type by ultrasound and incidence of cancer. J Clin Gastroenterol 1989;11:471-6.

3. Stephen AE, Berger DL. Cancer in the porcelain gallbladder: a relationship revisited. Surgery 2001;129:699-703.

This pdf has been created automatically from the final edited text and images.

Copyright 2012 BMJ Publishing Group. All rights reserved. For permission to reuse any of this content visit http://group.bmj.com/group/rights-licensing/permissions.

BMJ Case Report Fellows may re-use this article for personal use and teaching without any further permission.

Please cite this article as follows (you will need to access the article online to obtain the date of publication).

Gupta S, Jauhari RK. Rare presentation of porcelain gall bladder: carcinoma gall bladder with a large intra-abdominal cystic swelling. BMJ Case Reports 2012;10.1136/bcr-2012-006894, Published XXX

Become a Fellow of BMJ Case Reports today and you can:

- Submit as many cases as you like

- Enjoy fast sympathetic peer review and rapid publication of accepted articles

- Access all the published articles

- Re-use any of the published material for personal use and teaching without further permission

For information on Institutional Fellowships contact consortiasales@bmjgroup.com

Visit casereports.bmj.com for more articles like this and to become a Fellow 